\title{
STRATEGI PENGAJARAN DALAM PEMBELAJARAN DOKKAI SHOCHUKYU PADA MAHASISWA SEMESTER III PROGRAM STUDI PENDIDIKAN BAHASA JEPANG UNDIKSHA
}

\author{
I.M.K.Wijayadi ${ }^{1}$, I.W.Sadyana ${ }^{1}$, K.E.K.Adnyani ${ }^{2}$ \\ 123 Jurusan Pendidikan Bahasa Jepang, Universitas Pendidikan Ganesha, Singaraja,Bali \\ e-mail: kriswijayadi21@gmail.com,wayan.sadyana@undiksha.ac.id krishna.adnyani@undiksha.ac.id
}

\begin{abstract}
Abstrak
Penelitian ini bertujuan untuk menganalisis (1) penggunaan strategi pengajaran dalam pembelajaran dokkai shochukyu pada mahasiswa semester III Program Studi Pendidikan Bahasa Jepang Undiksha. Metode pengumpulan data menggunakan observasi,dokumentasi dan wawancara. Jenis penelitian ini adalah penelitian deskriptif kualitatif. Subjek yang digunakan dalam penelitian ini adalah dosen pengampu matakuliah dokkai shochukyu pada mahasiswa semester III Program Studi Pendidikan Bahasa Jepang Undiksha. Hasil penelitian menunjukan bahwa strategi yang digunakan dalam pembelajaran dokkai shochukyu adalah model pembelajaran cooperative learning tipe peer lesson. Hal ini terbukti pada setiap topik materi pembelajaran dijelaskan oleh mahasiswa secara berkelompok kepada mahasiswa lain melalui sebuah video yang kemudian dipresentasikan. Model pembelajaran cooperative learning tipe peer lesson ini dikombinasikan dengan strategi bottom-up pada tahap pembelajarannya, ini terlihat dari alur pembelajaran di dalam kelas, yaitu tahapan pembelajaran dimulai dari hal yang paling kecil yaitu pengenalan huruf kanji kemudian menuju ketahapan pembelajaran yang lebih besar yaitu menyimpulkan isi wacana.
\end{abstract}

Kata Kunci : Strategi pembelajaran, bahasa Jepang, dokkai shochukyu.

\section{要旨}

本研究の目的は、（1）ガネシャ教育大学の日本語教育学科二年生の読解初中級学習における指導戦 略を分析した。データは、授業観察、記録撮影 インタビューにより収集し、それを定性的記述法に より分析した。対象は、ガネシャ教育大学の日本語教育学科二年生読解初中級授業を担当する教師で ある。本研究の結果、読解初中級授業の使用される学習法モデルのコープラティプラーニングタイプ ピアレッスンである。これは、あるグループの学生が他のグループの学生に動画でトピックを説明し 発表したときに明らかある。学習段階においては、コープラティプラーニング学習方法のピアーレッ スンタイプはボトムアップのストラテジーと組み合わせていました。

キーワード : 学習法、日本語, 読解初中級

\section{Pendahuluan}

Bahasa Jepang merupakan salah satu bahasa asing yang diajarkan dalam pendidikan di Indonesia. Pembelajaran bahasa Jepang pada umumnya bertujuan agar pembelajarnya mampu berkomunikasi baik secara lisan maupun tulisan. (Sutedi, 2011:39). Maka dari itu penting bagi seorang pembelajar bahasa Jepang mampu menguasai empat keterampilan berbahasa Jepang yang meliputi: berbicara (hanasu ginou), mambaca (yomu ginou), mendengah (kiku ginou), dan menulis (kaku ginou). Dari keempat keterampilan tersebut, membaca merupakan keterampilan atau proses yang kognitif yang berupaya untuk menemukan informasi yang terdapat dalam tulisan. (Dalman, 2013:5). Dengan kata lain membaca adalah suatu proses yang dilakukan serta dipergunakan untuk memperoleh isi yang disampaikan oleh penulis kepada pembaca melalui kalimat yang tertuang dalam bahasa tulis.

Pembelajaran membaca dalam bahasa Jepang dikenal dengan istilah dokkai, kegiatan membaca dalam bahasa Jepang, selain proses memahami informasi, pembelajar bahasa 
Jepang dapat mengasah hampir seluruh aspek kemampuan berbahasa Jepangnya, yaitu kemampuan mengenali huruf kanji, katakana, dan hiragana. Selain itu kemampuan tata bahasa (hyougen bunkei), kemampuan menerjehkan (honyaku), dan kemampuan menganalisis informasi yang diperoleh dari kegiatan membaca.

Kemampuan dokkai yang baik sangat penting dimiliki oleh seseorang yang sedang belajar bahasa Jepang, apabila pembelajar bahasa Jepang tidak memiliki kemampuan membaca, maka dapat dipastikan akan sulit menyesuaikan diri dengan bahasa Jepang. Selain itu keterampilan berbahasa Jepangnya tidak akan berkembang karena tidak dapat memperoleh informasi lain dalam kegiatan belajarnya. Sehingga dalam praktiknya Program Studi Pendidikan Bahasa Jepang Univesitas Pendidikan Ganesha (Undiksha), menetapkan dokkai sebagai salah satu matakuliah wajib. Dokkai「読解」terdiri dari dua suku kata yaitu doku「読」dan kai「解」 yang berarti membaca dan pemahaman. Sehingga dapat disimpulkan bahwa dokkai dalam bahasa Indonesia berarti membaca pemahaman.

Berdasarkan buku pedoman studi program sarjana dan diploma Undiksha 2017, matakuliah dokkai diprogramkan untuk mahasiswa semester II sampai semester V dengan tingkat pembelajaran yaitu dokkai shokyu, dokkai shochukyu, dokkai chukyu, dan dokkai jokyu. Dalam penelitian ini yang digunakan sebagai contoh penelitian yaitu pada tingkatan pembelajaran dokkai shochukyu matakuliah yang diprogram oleh mahasiswa semester III dan telah lulusan dari dokkai shockyu. Mahasiswa yang mengambil matakuliah ini diharapkan telah mampu menguasai huruf kana (hiragana, katakana) dan sebagian huruf kanji dasar. Dalam proses pembelajaran dokkai shochukyu mahasiswa tidak lagi ditekankan pada pengenalan huruf per huruf maupun kata per kata, melainkan mahasiswa lebih banyak dilatih untuk dapat membaca kalimat, paragraf hingga wacana berbahasa Jepang tingkat dasar dan mampu untuk memahami makna yang terdapat dalam bacaan/wacana berbahasa Jepang. Pada tingkatan level shochukyu kompleksitas huruf kanji dalam kosakata mulai lebih banyak serta penyusunan kalimat-kalimat pada wacana lebih kompleks. Oleh karena itu mahasiswa sudah dapat diperkenalkan pada strategi- strategi membaca pemahaman.

Strategi pembelajaran yang tepat akan memudahkan mahasiswa dalam meningkatkan kemampuan membaca pemahaman. Mengingat akan pentingnya kemampuan membaca pemahaman, maka diperlukan upaya pengembangan strategi pembelajaran membaca pemahaman, peningkatan kualitas pembelajaran, diperlukan pengajaran yang lebih kreatif dapat membuat pembelajaran lebih menarik dan disukai peserta didik. Strategi yang diterapkan pengajar dalam mengajar mempengaruhi keefektifan dan keberhasilan pembelajaran. Pemilihan strategi yang tepat dapat menciptakan suasana belajar mengajar yang kondusif, sehingga pembelajar dapat dengan mudah menerima materi pembelajaran dengan baik. Selain itu, keberhasilan pembelajaran dan proses pengajaran itu efektif, seorang pengajar harus mengetahui startegi pembelajaran yang bervariasi dan tidak bertumpu pada satu metode saja. Strategi yang bervariasi dapat merubah kejenuhan pembelajar, sehingga menjadi lebih nyaman dan bersemangat dalam menerima pelajaran sehingga bisa mencapai prestasi belajar yang optimal.

Berdasarkan uraian latar belakang diatas, persoalan yang terjadi dapat diatasi dengan cara meningkatkan strategi pembelajaran membaca pemahaman mahasiswa. Mahasiswa harus menguasai kemampuan membaca pemahaman karena akan membantu dalam meningkatkan kemampuan belajar, memperluas pengetahuan dan wawasan secara umum, membiasakan diri berpikir kritis, dan membantu untuk aktif berpendapat. Berdasarkan uraian permasalahan diatas, maka dalam penelitian ini nantinya akan menghasilkan suatu gambaran mengenai strategi pengajaran dalam konteks pembelajaran membaca pemahaman bahasa Jepang tingkat dasar sebagai referensi dalam memilih strategi pembelajaran.

Maka dari itu latar belakang masalah yang dirumuskan rumusan dalam penelitian ini adalah sebagai berikut.

1. Bagaimanakah Strategi Pengajaran dalam Pembelajaran Dokkai Shochukyu pada Mahasiswa Semester III Program Studi Pendidikan Bahasa Jepang Undiksha? 
Dari rumusan masalah yang telah dirumuskan, maka tujuan penelitian ini adalah untuk menganalisis strategi pengajaran dalam pembelajaran dokkai shochukyu pada mahasiswa semester III Program Studi Pendidikan Bahasa Jepang Undiksha.

Menutut Hodsgon (dalam Tarigan 2008:7) kegiatan membaca adalah suatu proses yang dilakukan dan digunakan oleh pembaca untuk memperoleh pesan atau informasi yang hendak disampaikan oleh penulis melalui media kata-kata atau bahasa tulis. Sedangkan menurut Nurhadi (1995:34) Membaca adalah suatu interpretasi simbol-simbol tertulis atau membaca adalah menangkap makna dari serangkaian simbol-simbol

Berdasarkan pengertian tersebut dapat disimpulkan bahwa membaca adalah proses yang dilakukan oleh pembaca untuk memperoleh informasi melalui media kata-kata atau tulisan yang berasal dari teks atau bacaan serta memahami makna didalamnya. Membaca juga dapat dikatakan sebagai kegiatan mencermati tulisan, menelaah isi atau maksudnya untuk menyerap informasi.

\section{Membaca Pemahaman Bahasa Jepang (Dokkai)}

Secara harfiah dokkai diartikan dengan reading comprehension atau membaca pemahaman. Menurut kamus Nihon Kokugo Daijiten definisi dokkai adalah sebagai berikut.

読解は文章を読んで内容を理解する。

/Dokkai towa bunshou wo yonde naiyou wo rikai suru. /

"Dokkai adalah membaca kalimat- kalimat dari suatu bacaan kemudian memahami isi bacaan tersebut".

Sedangkan menurut Himeno (1998:87) bahwa dokkai adalah sebagai berikut.

読む事には、ただ表面には現れていることだけでなく、その背後にあるのも合わ

せて理解すると言いう意味が含まれていることに気つく

/Yomu koto ni wa, tada hyoumen ni wa arawarete iru koto dake de naku, sono haigo ni aru no mo awasete rikai suru to iiu imi ga fukumarete iru koto ni kitsuku. I

"Dalam hal membaca, tidak hanya hal-hal di luar saja yang harus diperhatikan, tetapi juga arti yang berada di balik tulisan atau bacaan tersebut."

Maka dari itu dapat disimpulkan bahwa dokkai sebagai membaca pemahaman merupakan suatu proses yang digunakan untuk memperoleh informasi, serta memahami isi atau makna yang terdapat dalam bacaan atau wacana.

\section{Proses Pengajaran Membaca Pemahaman Bahasa Jepang ( Dokkai)}

Menurut Sudjianto (2010:7) proses pengajaran dokkai terdiri dari tiga tahapan yaitu tahap prakegiatan (kegiatan persiapan), tahap kegiatan utama dan tahap pasca kegiatan yang harus dipikirkan untuk membuat pembelajaran sesuai alur yang terdiri dari kegiatan sebelum membaca, kegiatan membaca, dan kegiatan setelah membaca'.Alur kegiatan membaca dapat digambarkan sebagai berikut:

a. Mae Sagyou (前作業) Kegiatan awal (kegiatan persiapan). Pada tahap pra membaca dilakukan pembahasan-pembahasan umum tentang topik yang ada dalam bacaan. Kegiatan ini dimaksudkan untuk mengaktifkan pengetahuan awal siswa tentang topik yang terdapat dalam bacaan.

b. Hon Sagyou (本作業) Kegiatan inti (kegiatan dokkai) Pada saat membaca, siswa akan menggunakan pengetahuan ini dalam usaha memahami teks. Dengan demikian, siswa akan dapat lebih mudah memperoleh pemahaman.

c. Ato Sagyou (後作業) Kegiatan akhir (Kegiatan Pengecekan Pemahaman) Pengecekan pemahaman siswa ini akan dilakukan setelah aktivitas membaca.

\section{Dokkai Shochukyu}

Berdasarkan buku pedoman studi Undiksha tahun 2017 dalam pembelajaran dokkai terdapat tingkatan level pembelajaran yaitu yang dimulai dari level dasar dokkai shokyu, dokkai shochukyu, dokkai chukyu dan dokkai chujokyu. Pada penelitian ini yang digunakan sebagai contoh penelitian adalah pada dokkai Shochukyu yang merupakan level pembelajaran dokkai tingkat dasar-menengah. 
Matakuliah dokkai shochukyu di Program Studi Pendidikan Bahasa Jepang Undiksha yang diprogramkan untuk mahasiswa semester III. Sebagaimana yang dijelaskan dalam silabus perkuliahan matakuliah dokkai shochukyu 2017 bahwa materi yang dimuat dalam perkuliahan ini yaitu bertujuan untuk melatih mahasiswa dapat membaca wacana bahasa Jepang tingkat dasar, menambah perbendaharaan kosa kata, serta ungkapan dan kemampuan membaca huruf kana maupun huruf kanji. Dengan indikator pencapaian yang diharapkan yaitu mahasiswa mampu dalam memahami teks/wacana sederhana dengan baik serta dapat menceritakan kembali isi wacana, menemukan ide pokok dalam setiap paragraf, menentukan tema wacana secara keseluruhan dan menambah perbendaharaan kata-kata serta kemampuan membaca huruf Jepang.

\section{Model- Model Strategi Pembelajaran Membaca Pemahaman Bahasa Jepang (Dokkai)}

\section{a. Strategi Bawah-Atas (Bottom-Up)}

Menurut Johnson (271:2001) istilah bottom up ini digunakan karena pada proses ini pembaca memulai dari dasar, dengan teks itu sendiri. Istilah lain yang digunakan oleh ahli psikologi untuk proses yang sama bahkan menjadikan gagasan itu lebih jelas adalah "data driven processin". Data, dalam hal ini berupa huruf-huruf dan kata pada lembar halaman.Adapun tahapan pembelajaran strategi Bottom-Up ini sebagai berikut :

Tahapan dalam Strategi Bawah-Atas (Bottom-Up)

1. Menerjemahkan huruf dalam wacana dan mencari artinya.

2. Mencari kosakata baru dan mengartikannya.

3. Menerjemahkan kalimat demi kalimat, kemudian paragraf demi paragraf.

\section{b. Stretegi Atas-Bawah (Top-Down)}

Menurut Samuel dan Kamil strategi atas-bawah merupakan kebalikan dari strategi bawah-atas. Pada strategi atas-bawah, pembaca memulai proses pemahaman teks dari tataran yang lebih tinggi menuju ketataran pemahaman teks yang lebih rendah. Dalam hal ini, pembaca mulai dari prediksi, kemudian mencari input untuk mendapatkan informasi yang cocok dalam teks. Adapun tahapan pembelajaran strategi Bottom-Up ini sebagai berikut :

Tahapan dalam Stretegi Atas-Bawah (Top-Down)

1. Membaca dengan tujuan hanya mencari informasi yang diperlukan saja.

2. Membaca secara keseluruhan dan memahami makna inti dari wacana.

3. Membaca sambil memprediksikan isi wacana.

4. Mencari kosakata, ungkapan, atau kalimat yang diperlukan saja sementara yang lainnya yang dianggap tidak perlu tidak diindahkan.

\section{c. Strategi Interraktif (Gabungan)}

Proses membaca interaktif merupakan kombinasi dari model membaca bawah-atas (Bottom-up) dan model membaca atas-bawah (Top-down). Proses membaca dengan model interaktif ini menggunakan strategi-strategi model atas-bawah dan model bawah-atas dengan bergantian untuk memperoleh pemehaman dari teks yang dibaca. Pada model membaca interaktif, untuk memahami isi teks pembaca melakukan penggabungan model antara Top-down dengan model Bottom-up.

\section{Metode}

Jenis penelitian ini tergolong penelitian deskriftif kualitatif, rancangan ini dipilih karena sesuai dengan tujuan penelitian yaitu menganalisis penggunaan strategi pengajaran dalam pembelajaran dokkai shochukyu. Menurut Best (dalam Sukardi 2005) adalah metode penelitian yang berusaha menggambarkan dan menginterpretasikan objek sesuai dengan apa adanya.

Metode pengumpulan data yang digunakan untuk memperoleh serta mengumpulkan informasi (data) mengenai strategi pengajaran yang digunakan dosen dalam pembelajaran dokkai shochukyu yaitu:

(a) Metode Observasi

(b) Metode Dokumentasi 
(c) Metode Wawancara.

Data yang terkumpul dalam penelitian ini berupa data kualitatif, yaitu berupa data observasi, data hasil dokumentasi dan data hasil wawancara mengenai jenis strategi pengajaran yang digunakan dosen dalam pembelajaran dokkai shochukyu. Setelah data terkumpul, data diolah dengan analisis deskriptif-kualitatif yaitu penggambaran secara sistematis, jelas dan obyektif dengan cara mengidentifikasi data, mengklasifikasi data, menganalisis data, dan merumuskan simpulan.

\section{Hasil dan Pembahasan}

Observasi I dilakukan pada tanggal 30 Agustus 2017 dengan topik wacana yang dibahas berjudul 小説家の一生(shousetsuka no issyou /riwayat hidup) halaman 44. Dalam buku みんなの日本語初級1初級で読めるトピック(minna no nihongo shokyou 1 shokyu yomeru topikku)

\section{a. Mae Sagyou (前作業) Kegiatan awal pembelajaran}

Dosen memasuki ruangan pada jam $\mathrm{G}$ yaitu jam 13.30. Dosen membuka perkuliahan dengan mengucapkan salamこんにちはdan mengecek kehadiran mahasiswa. Setelah selesai mengecek kehadiran mahasiswa, kegiatan pembelajaran langsung diserahkan kepada mahasiswa yang bertugas (kelompok pertama).

Kelompok pertama bertugas menjelaskan atarashii kotoba (kosa kata baru) dan atarashii kanji (huruf kanji baru) yang terdapat dalam wacana 小説家の一生(shousetsuka no issyou). Penjelasan huruf kanji dan kosakata tersebut direkam dan dijadikan sebagai video pembelajaran. Video pembelajaran yaitu video rekaman penjelasan huruf kanji dan kosakata seluruh anggota kelompok tersebut disajikan atau dipresentasikan oleh kelompok pertama kepada mahasiswa lainnya di kelas. Dalam video yang dipresentasikan mahasiswa menyajikan penjelaskan arti dan cara baca kanji serta arti dari beberapa kosakata (atarashii kotoba) yang terdapat dalam wacana 小説家の一生(shousetsuka no issyou). Pada kegiatan presentasi yang sedang berlangsung mahasiswa lain memperhatikan serta mecatat hal-hal yang menurutnya penting.

Presentasi dilaksanakan kurang lebih selama 10-15 menit, kegiatan setelah presentasi, dilanjutkan dengan kuis atau sesi tanya jawab. Setiap kelompok diwajibkan menyiapkan minimal lima pertanyaan kepada teman-temannya mengenai materi yang dipresentasikan dengan menggunakan power point. Teknis tanya jawab disini yaitu peserta kelompok menunjukan huruf kanji menggunakan power point kemudian menunjuk salah satu mahasiswa untuk menyebutkan arti dan cara baca huruf kanji yang ditunjukan tersebut. Bagi mahasiswa yang ditunjuk dan bisa menjawab dengan benar maka mahasiswa tersebut berhak menunjuk temannya untuk mendapatkan giliran berikutnya. Dosen yang dibantu oleh mahasiswa lain mengevaluasi kejelasan gambar, tulisan serta suara dari video yang dipresentasikan dari kelompok yang bertugas (kelompok pertama). Evaluasi ini dilakukan dengan cara dosen menuliskan dan mahasiswa menyebutkan kekurangan dan kelebihan dari video tersebut. Tujuan dari evaluasi ini yaitu untuk dapat menjadi bahan masukan bagi kelompok mahasiswa yang akan presentasi berikutnya. Kegiatan ini terus berlangsung sampai semua pertanyaan habis dijawab. Setelah kegiatan tanya jawab dosen mengambil alih kontrol kegiatan pembelajaran dengan melakukan kegiatan evaluasi.

Dosen yang dibantu oleh mahasiswa lain mengevaluasi kejelasan gambar, tulisan serta suara dari video yang dipresentasikan dari kelompok yang bertugas (kelompok pertama). Evaluasi ini dilakukan dengan cara dosen menuliskan dan mahasiswa menyebutkan kekurangan dan kelebihan dari video tersebut. Berikut adalah beberapa penjelasan dosen dalam slide power point.

Tujuan dari evaluasi ini yaitu untuk dapat menjadi bahan masukan bagi kelompok mahasiswa yang akan presentasi berikutnya.

Setelah kegiatan evaluasi, dosen mulai masuk kedalam pembahasan wacana dengan memberikan penjelasan/gambaran awal kepada mahasiswa mengenai judul wacana 小説家の一生 (shousetsuka no isshou). Apabila judul tersebut diterjemahkan kedalam bahasa Indonesia berarti riwayat hidup. Selanjutnya dosen menggunakan media power 
point berupa slide dalam memberikan menjelaskan mengenai wacana小説家の一生 (shousetsuka no isshou) .

Berikut adalah beberapa penjelasan dosen dalam slide power point.

1. Natsume Souseki（夏目漱石）(そうせき、Souseki) merupakan nama popular Natsume Kinnousuke（夏目勤皇輔）

2. Natsume Souseki merupakan penulis novel yang terkenal pada zamannya. Banyak novel yang ditulisnya seperti : I AM A CAT (我輩は 猫である,MASTER DARLING（ぼち やん) SANSHIRO (さんしろ)

3. Natsume Souseki (夏目漱石) adalah orang yang wajahnya pernah dicetak pada pecahan mata uang Jepang 1000 yen pada tahun 1984 .

4. Natsume Souseki (夏目漱石) dianggap sebagai salah satu novelis terbaik di Jepang pada zamannya.

Dari kegiatan ini dapat disimpulkan bahwa mahasiswa mendapat gambaran awal pada kegiatan sebelum membaca, bahwa wacana小説家の一生 (shousetsuka no isshou) menceritakan tentang perjalanan hidup atau riwayat hidup dari seorang tokoh novelis Jepang yang terkenal pada zamannya yaitu Natsume Souseki（夏目漱石）.

Berdasarkan pemaparan hasil observasi dapat disimpulkan bahwa tahapan pembelajaran yang dilakukan oleh dosen pada tahap mae sagyou atau kegiatan awal pembelajaran dapat diketahui sebagai berikut:

1. Pembelajaran huruf. Huruf kanji dan beberapa kosakata baru yang terdapat dalam wacana dijelaskan oleh mahasiswa secara berkelompok. Penjelasan tersebut direkam kemudian dijadikan sebagai video pembelajaran. Video pembelajaran tersebut disajikan atau dipresentasikan kepada mahasiswa lainya di kelas.

2. Dosen menjelaskan beberapa hal dari materi dengan tujuannya memberikan pengetahuan awal kepada mahasiswa agar nantinya lebih mudah dalam memahami isi bacaan dalam proses membaca.

\section{b. Hon Sagyou (本作業) Kegiatan inti pembelajaran /kegiatan membaca}

Hon sagyou merupakan kegiatan inti pembelajaran yang dilakukan setelah kegiatan awal pembelajaran atau tahap mae sagyou. Pada kegiatan ini mahasiswa membaca wacana perkalimat secara bergiliran kemudian menerjemahkan kalimat yang dibacanya tersebut kedalam bahasa Indonesia.

Kegiatan hon sagyou yang diterapakan pada pembelajaran dokkai shochukyu ini sejalan dengan pengertian dokkai menurut Kimura (dalam Apriani 2009:21) definisi dokkai adalah sebagai berikut:

読解は文章を読んで内容を理解する。

/Dokkai towa bunshou wo yonde naiyou wo rikai suru. /

"Dokkai adalah membaca kalimat-kalimat dari suatu bacaan kemudian memahami artinya.

Menerjemahkan kalimat tersebut bertujuan untuk mengetahui sejauh mana mahasiswa mampu memahami isi kalimat yang dibacanya. Tentunya hal ini tidak mudah bagi mahasiswa karena dalam setiap kalimat dalam wacana terdapat beberapa huruf kanji yang harus dimengerti baik cara bacanya maupun artinya agar dapat menerjemahkan kalimat secara utuh dengan baik dan dapat dimengerti. Sering kali mahasiswa dibantu dosen dalam menerjemahkan ketika menemukan kata-kata yang sulit serta kalimat yang panjang dan tidak dimengerti artinya. 
Berikut ini beberapa contoh kalimat yang dibaca dan diterjemahkan oleh mahasiswa.

a. 1867 年、東京でうまれた。

/ 1867 Nen, Tokyo de umareta /

'Lahir di Tokyo pada tahun 1867'.

b. 1890 年、東京大学に 入った。

/ 1890 Nen, Tokyo Daigaku ni haitta /

'Kuliah di Univerasitas Tokyo pada tahun 1890'.

c. 大学を 出てから、松山や 熊本の 学校で 英語を 教えた。

/ Daigaku wo detekara, Matsuyama ya Kumamoto no gakkou de eigo wo oshieta /

'Setelah lulus kuliah, mengajar bahasa Inggris di sekolah Matsuyama dan Kumamoto'.

d. 1896 年、熊本で 結婚した。

/ 1896 Nen, Kumamoto de kekkon shita /

'Menikah di Kumamoto pada tahun 1896'

Kegiatan membaca ini terus berlangsung secara bergiliran sampai semua kalimat dalam wacana habis dibaca dan diterjemahkan. Bagi mahasiswa yang tidak mendapat giliran atau mahasiswa yang mendapat giliran paling terakhir ditunjuk dosen untuk menyimpulkan seluruh isi wacana yang telah dibaca secara singkat dengan bahasa Indonesia. Setelah mahasiswa menyimpulkan, dosen menambahkan kembali beberapa hal terkait isi wacana guna memperbaiki terjemahan dan kesimpulan dari mahasiswa.

\section{c. Ato Sagyou（後作業）/Kegiatan akhir pembelajaran}

Kegiatan ini merupakan proses akhir dari kegiatan pembelajaran. Dimana dalam pembelajaran dokkai shochukyu, proses input pembelajaran di dapat pada kegiatan mae sagyou dan hon sagyou. Pada kegiatan mae sagyou mahasiswa menyimak penjelasan mengenai huruf kanji dan kosakata baru yang terdapat pada wacana小説家の一生 (shousetsuka no isshou). Kemudian pada kegiatan hon sagyou mahasiswa membaca dan menerjemahkan wacana小説家の一生 (shousetsuka no isshou) secara langsung serta memahami makna dan informasi yang terkandung dalam wacana tersebut. Sedangkan proses output pembelajaran sebagai proses evaluasi pemahaman mahasiswa dilaksanakan pada kegiatan akhir pembelajaran (ato sagyou). Kegiatan pengecekan pemahaman ini dilakukan dengan membahas soal pertanyaan yang ada dalam wacana tersebut. Dalam hal ini dosen kembali menggunakan alat bantu berupa media power point untuk menunjukan gambar uang Jepang kepada seluruh mahasiswa di kelas.

Adapun beberapa contoh pertanyaan yang dibahas, adalah sebagai berikut.

1.この人は。。。。?日本人はみんなこの人を知っています。

/kono hito wa...? Nihon jin wa minna kono hito wo shiteimasu /

2. 夏目漱石です。

/Natsume Souseki desu /

A. 彼はたくさん小説を書きました。1905年に。。。??書きました。

IKare wa takusan shousetsu wo kakimashita. 1905 Nen ni...? wo kakimashita I

B. 我輩は猫であるです。

/wagahai ha neko de aru desu. /

Pembahasan ini dilakukan sampai semua pertanyaan-pertanyaan yang ada terjawab dan mahasiswa bisa memahami wacana tersebut dengan baik.

Terakhir, dosen bertanya “じや、皆さん質問がありますか”。dan ditanggapi oleh mahasiswa, dengan menjawab “いいえ、ありません”。Dosen kemudian mengakhiri perkuliahan, dengan mengucapkan “じゃ、質問がなかったら、これ終わりました”。 Mahasiswa membalas dengan ucapan “どうも、ありがとうございます。

\section{Analisis Hasil Penelitian}

Jurnal Pendidikan Bahasa Jepang | 116 
Berdasarkan hasil wawancara pada hari Senin 18 Desember 2017, dalam pembelajaran dokkai shochukyu dosen menggunakan strategi pembelajaran peer lesson dan Bottom-up. Strategi peer lesson digunakan untuk mendukung pembelajaran yang aktif yang bersumber pada mahasiswa. Model pembelajaran yang dikembangkan oleh dosen merupakan pembelajaran aktif (active learning) yang mana dalam proses pembelajaran dokkai shochukyu, aktivitas pembelajaran didominasi oleh mahasiswa, dosen hanya sebagai fasilitator, membimbing mahasiswa belajar, memberikan evaluasi pelaksanaan pembelajaran.

Dari hasil penelitian yang dipaparkan melalui observasi ke-I, II, III dan juga pengamatan hasil dokumentasi dapat dianalisis bahwa strategi peer lessson yang digunakan merupakan strategi pengajaran sesama teman yaitu teknik penyampaian materi melalui rekan atau bantuan teman sendiri atau dikenal dengan pengajaran teman sebaya. Dalam pembelajaran dokkai shochukyu strategi ini diterapkan pada pembelajaran atau pengenalan huruf kanji. Kegiatan pembelajaran atau pengenalan huruf kanji ini dilaksanakan pada tahap mae sagyou atau kegiatan diawal pembelajaran. Hal ini sejalan dengan pendapat yang disampaikan oleh Silberman (2009:173) yang berpendapat bahwa "strategi peer lesson merupakan bagian dari pembelajaran aktif dan juga strategi untuk mendukung pengajaran sesama siswa atau pengajaran dari teman sebaya yang memungkinkan siswa saling mengajar di dalam kelas".

Pada pembelajaran dokkai shochukyu dosen juga menggunakan strategi bottom up. Strategi ini digunakan untuk mendukung pengajaran dokkai yang aktif dan komunikatif yaitu pengajaran yang menekankan pada aspek komunikasi, interaksi, dan mengembangkan kompetensi kebahasaan serta keterampilan berbahasa mahasiswa. Pengajaran dokkai dengan model ini yaitu proses membaca dimulai dengan pemahaman dari satuan terkecil yaitu huruf menuju satuan yang lebih besar yaitu kosakata, kalimat, dan terakhir memahami wacana secara keseluruhan. Hal ini sejalan dengan pendapat yang diungkapkan oleh Brown (dalam Subadiyono: 12:2014) yaitu "proses membaca model bottom-up mulai dari mengidentifikasi huruf-huruf, kata, frasa, kalimat dan terus bergerak ketataran yang lebih tinggi, sampai akhirnya bisa memahami isi teks".

Model pengajaran dokkai shochukyu dengan strategi bottom-up dalam pembelajaran dokkai shochukyu dapat digambarkan sebagai berikut.

1. Menerjemahkan huruf-huruf dalam wacana dan mencari artinya

2. Mencari kosakata baru dan mengartikannya

3. Membaca dan menerjemahkan kalimat demi kalimat, kemudian memahami dan menyimpulkan seluruh isi wacana.

Pada pembelajaran dokkai shochukyu jika dilihat dari tahapan pembelajaran yang dipaparkan pada observasi I, II, III alur pembelajaran mencirikan strategi pembelajaran bottom-up, yang mana penyajian materi dimulai dari pengenalan/pembelajaran huruf kanji yang dilaksanakan pada tahapan mae sagyou atau kegiatan diawal pembelajaran, kemudian membaca kalimat, menerjemahkan kalimat, dan terakhir menyimpulkan isi wacana dilaksanakan pada tahapan hon sagyou atau kegiatan membaca wacana (inti pembelajaran). Dalam hal ini mahasiswa berinteraksi secara aktif dalam menerjemahkan huruf-huruf dalam wacana dan mencari artinya, dan mencari kosakata baru dan mengartikannya kemudian membaca dan menerjemahkan kalimat demi kalimat dalam wacana serta memahami dan menyimpulkan seluruh isi wacana.

Strategi pengajaran peer lesson dan strategi bottom-up yang digunakan dosen dalam pembelajaran dokkai shochukyu dalam hal berbasis kurikulum (SKKNI) Standar Kerangka Kualifikasi Nasional Indonesia yang diatur dalam Peraturan Presiden Republik Indonesia Nomor 8 Tahun 2012 Tentang Kerangka Kualifikasi Nasional Indonesia, pasal 1 ayat (2), menjelaskan bahwa dalam kurikulum KKNI terdapat capaian pembelajaran yang merupakan suatu ungkapan atau tujuan pendidikan tentang apa yang diharapkan, diketahui, dipahami, dan dapat dikerjakan oleh peserta didik setelah menyelesaikan suatu periode belajar.

Berdasarkan analisis yang dipaparkan maka pembahasan dalam penelitian ini difokuskan pada 3 pokok pembahasan adalah sebagai berikut: 
1. Upaya Pemenuhan Turunan Capaian Pembelajaran yang diperoleh dari Internalisasi Pengetahuan, Sikap, Keterampilan Umum dan Keterampilan Khusus dalam Kurukulum KKNI dengan Strategi Pengajaran Peer Lesson dan Strategi Bottom-up dalam Pembelajaran Dokkai Shochukyu.

2. Garis Besar Strategi Pengajaran Peer Lesson dan Strategi Bottom-Up dalam Pembelajaran Dokkai Shochukyu.

Langkah-Langkah Strategi Pengejaran Peer Lesson dan Strategi Bottom-Up dalam Pembelajaran Dokkai Shochukyu.

\section{PEMBAHASAN}

Upaya Pemenuhan Turunan Capaian Pembelajaran yang diperoleh dari Internalisasi Pengetahuan, Sikap, Keterampilan Umum dan Keterampilan Khusus dalam Kurukulum KKNI dengan Strategi Pengajaran Peer Lesson dan Strategi Bottom-up dalam Pembelajaran Dokkai Shochukyu.

\section{1) Sikap}

\section{a) Memiliki Tanggung Jawab dalam Menyelesaikan Tugas}

Untuk memiliki tanggung jawab dalam menyelesaikan tugasnya, dosen membentuk mahasiswa menjadi kelompok yang dibentuk pada pertemuan pertama (kontrak kelas) kemudian membagikan materi tugas yang harus dikerjakan oleh mahasiswa secara berkelompok. Dalam pelaksanaannya yaitu:

1. Mahasiswa dibagi menjadi kelompok, dengan jumlah 3-4 orang mahasiswa.

2. Masing-masing kelompok mendapat 1 wacana sebagai tugas yang harus dikerjakan. Wacana tersebut diambil dari buku pedoman perkuliahan yang berjudulみんなの日本語 初級1初級で読めるトピック(minna no nihongo shokyou 1 shokyu yomeru topikku).

3. Tugas dari dari masing-masing kelompok yaitu mencari kemudian menjelaskan huruf kanji (atarashii kanji) dan kosakata baru (atarashii kotoba) yang terdapat dalam wacana. Penjelasan tersebut direkam dijadikan sebagai video pembelajaran.

4. Video pembelajaran yaitu rekaman seluruh anggota kelompok dalam menjelaskan cara baca huruf kanji serta arti dan bebrapa kosakata baru tersebut dipresentasikan atau disajikan kepada mahasiswa lainnya di kelas. Dalam hal ini mahasiswa diberi kesempatan dalam penyampaian materi untuk menggunakan berbagai cara atau metode yang sesuai dengan materi yang mereka dapatkan, bisa dengan cara mendongeng, diperagakan sendiri, menggunakan kartu bergambar, diperagakan boneka, wayang, dijadikan musikalisasi puisi dan bisa juga dilengkapi dengan subtitle video sederhana yang dibuat dengan hand phone, menggunakan e-kaado atau moji kado, sehingga mahaiswa mampu untuk menguasai materinya.

Kegiatan ini merupakan bagian dari strategi pengajaran active learning tipe peer lesson, yang mana mahasiswa secara berkelompok diberikan tangguang jawab sepenuhnya dalam menyelesaikan tugasnya, dan bertanggung jawab untuk mempresentasikan tugasnya tersebut kepada mahasiswa lain.

\section{b) Mampu Berkomunikasi Secara Lisan dan Tertulis}

Tujuan utama pembelajaran bahasa Jepang yaitu agar pembelajarnya mampu berkomunikasi secara lisan dan tertulis (Sutedi 2011:39). Pembelajar bahasa Jepang harus dapat menguasai empat keterampilan berbahasa Jepang yang terdiri atas kiku nouryoku(menyimak), hanasu nouryoku (berbicara), yomu nouryoku (membaca), dan kaku nouryoku(menulis) untuk mampu berkomunikasi secara lisan dan tertulis,

Maka dari itu untuk melatih agar mahasiswa mampu berkomunikasi secara lisan dan tertulis dan juga dalam upaya memenuhi turunan capaian pembelajaran, maka dosen menerapkan pengajaran dalam pembelajaran dokkai shochukyu, adalah sebagai berikut:

a. Keterampilan menyimak dan berbicara, dalam proses pembelajaran dokkai shochukyu di kelas, dosen menggunakan bahasa Jepang sebagai bahasa pengantar pembelajaran, 
hal ini secara tidak langsung mendorong mahasiswa untuk menyimak dan berkomunikasi dalam bahasa Jepang dengan dosen selama perkuliahan. Dalam kegiatan presentasi juga mahasiswa disuruh aktif menggunakan bahasa Jepang, baik itu dalam membuka presentasi maupun menutup jalannya presentasi.

b. Keterampilan membaca, dokkai merupakan matakuliah membaca pemahaman, dalam proses pembelajaran dokkai shochukyu mahasiswa disuruh untuk membaca wacana perkalimat secara bergiliran untuk melatihan kemampuan membaca setiap mahasiswa.

c. Keterampila menulis, dalam proses pembelajaran mahasiswa secara tidak langsung dituntut untuk mencatat materi pembelajaran yang penting baik itu atarahii kotoba (kosakata baru) maupun atarashii kanji (huruf kanji baru) yang disertai dengan cara baca kanji tersebut. Baik itu digunakan untuk kepentingan masing-masing maupun untuk kepentingan dalam menerjemahkan kalimat- kalimat dalam wacana yang dibahas.

Strategi pembelajaran ini merupakan bagian dari stretegi active learning Mahasiswa secara aktif menggunakan kemampuan yang dimilikinya untuk berkomunikasi dalam proses pembelajaran dan juga secara tidak langsung melatih mahasiswa agar mampu untuk dapat berkomunikasi secara lisan dan tertulis.

c) Menghargai Keanekaragaman Budaya dan Pandangan yang Terkait dengan Materi

\section{Bacaan Tingkat Dasar}

Dalam upaya memenuhi turunan capaian pembelajaran ini, yaitu untuk menerapkan sikap menghargai keanekaragaman budaya dan pandangan yang terkait dengan materi bacaan, dosen menyajikan beberapa penjelasan yang diambil dari wacana yang berjudul 説家の一生(shousetsuno issyou) pada halaman 44 buku pedoman perkuliahan みんなの日本 語初級1初級で読めるトピック(minna no nihongo shokyou 1 shokyu yomeru topikku). Wacana ini menyajikan tentang:

1. Perjalanan hidup penulis novel terkenal di Jepang yang bernama Natsume Souseki.

2. Judul-judul novel terkenal karya Natsume Souseki,

2. Judul-judul novel terkenal karya Natsume Souseki, seperti : I AM A CAT (我輩は猫

である,MASTER DARLING（ぼちゃん） SANSHIRO（さんしろ）

Dari perjalanan hidup Natsume Souseki ini mahasiswa belajar mengenai pandangan orang Jepang terhadap karya seseorang. Dalam hal ini, dosen menjelaskan bahwa orang Jepang saat ini menghargai dan mengenal Natsume Souseki lewat karya-karyanya, bahkan pada tahun 1984 Natsume Souseki merupakan orang yang wajahnya dicetak pada lembaran uang 1000 yen Jepang. Banyak karya novel tulisan Natsume Souseki yang diterjemahkan kedalam bahasa Inggris. Sepeti: Bochan, wagai wa neko de aru, Sanshiro.

Strategi pengejaran ini merupakan bagian dari strategi bottom-up yaitu upaya dosen dalam memberikan gambaran pada mahasiswa mengenai materi yang dibahas pada kegiatan sebelum membaca. Dosen menggunakan alat bantu berupa media power point dalam menyampaian pembahasan ini.

\section{2) Pengetahuan}

a) Memiliki Pengetahuan Dasar - Dasar Sosial dan Budaya Jepang yang di Dapatkan dari Materi Bacaan

Dalam upaya memenuhi turunan capaian pembelajaran ini, dosen memberikan pengetahuan kepada mahasiswa tantang dasar-dasar sosial dan budaya Jepang lewat wacana berjudul コーヒーを飲むと(koohii wo nomu to) halaman 56, buku pedoman perkuliahan みんなの日本語初級1初級で読めるトピック(minna no nihongo shokyou 1 shokyu yomeru topikku).

Wacana ini menyajikan sejarah kopi, yaitu masuknya kopi dan perkembangan kopi di Jepang. Mahasiswa belajar mengenai dasar-dasar sosial dan budaya Jepang lewat pembahasan yang disampaikan dosen, yang menjadi poin penting dalam pembahasan yang disampaikan dari wacana ini yaitu:

4. Kopi masuk ke Jepang dibawa oleh orang Belanda kira - kira pada 200 tahun yang lalu. 
5. Orang Jepang pertama kali minum kopi pada zaman Meiji, tetapi sekarang di Jepang 1 orang bisa minum kopi kira-kira 300 cangkir dalam satu tahun.

6. Orang Jepang membuktikan bahwa kopi memiliki bermacam-macam manfaat bagi tubuh Hal ini secara tidak langsung menjadi pengetahuan bagi mahasiswa mengenai budaya Jepang yang berkembang yang di dapat lewat materi bacaan. Strategi pembelajaran ini merupakan bagian dari upaya dosen dalam memberikan gambaran pada mahasiswa mengenai materi yang dibahas pada kegiatan sebelum membaca. Dalam penyampaian pembahasan ini dosen menggunakan alat bantu berupa media power point untuk mempermudah menyampaikan penjelasan kepada mahasiswa.

\section{b) Menguasai Konsep Dasar Perbandingan Budaya dan Pola Pikir antara Orang Indonesia dan Orang Jepang}

Dalam upaya dosen memberi pengetahuan mahasiswa agar dapat menguasai konsep dasar perbandingan budaya dan pola pikir antara orang Jepang dan orang Indonesia dalam pembelajaran di kelas, dosen membadingkan pola pikir orang Indonesia dengan orang Jepang lewat perbandingan peribahasa atau kotowaza dalam bahasa Jepang. Pembahasan ini disajikan dalam wacana yang berjudul 雨降って地固まる (ame futte, ji katamaru), halaman 48, buku pedoman perkuliahanみんなの日本語初級1初級で読めるトピック(minna no nihongo shokyou 1 shokyu yomeru topikku). Judul wacana ini merupakan sebuah kotowaza atau peribahasa, yang dimana dalam bahasa Indonesia mempunyai arti 'Hujan turun, tanah pun jadi menggumpal'.

Tema pembahasan dalam wacana ini adalah judul wacana, dosen menyampaikan makna dari kotowaza tersebut yang mana memiliki makna "Setelah menghadapi permasalahan, mental kita menjadi lebih kuat dari sebelumnya." Dalam bahasa Indonesia dosen membandingkan peribahasa ini dengan "berakit-rakit kita ke hulu, berenang- renang ketepian" yang dimana peribahasa Indonesia ini mengandung makna "bersakit - sakit dulu, bersenang- senang kemudian" Dosen memberikan pengertian budaya dan konsep pola pikir secara sederhana dengan membandingkan peribahasa dari kedua bahasa dalam usaha memberikan pemahaman pengetahuan mengenai perbedaan budaya antara orang Jepang dan orang Indonesia kepada mahasiswa.

Strategi pembelajaran ini merupakan bagian dari upaya dosen dalam memberikan tambahan pengetahuan pada mahasiswa tentang materi yang dibahas pada kegiatan sebelum membaca. Dalam penyampaian pembahasan ini dosen menggunakan alat bantu berupa media power point untuk mempermudah menjelaskan maksud yang ingin disampaikan kepada mahasiswa.

\section{3) Keterampilan Umum}

a) Mampu Mengaplikasikan Kemampuan Bahasa Jepang dengan Menunjukan Penguasaan yang Baik pada Aspek Tata Bahasa, Kosakata, dan Huruf Jepang Tingkat Dasar.

Pengaplikasian kemampuan bahasa Jepang yang menunjukan penguasaan tata bahasa, kosakata, dan huruf Jepang tingkat dasar dapat dilihat dari kemampuan mahasiswa dalam membaca dan menerjemahkaan wacana kedalam bahasa Indonesia. Dalam membaca kalimat bahasa Jepang terdapat beberapa huruf kanji yang harus dipahami baik arti maupun cara bacanya, dan dalam proses menerjemahkan mahasiswa juga harus memperhatikan tata bahasa maupun pembentukan pola kalimat agar dapat menerjemahkan kalimat tersebut dengan baik, tentunya keterampilan mahasiswa dalam penguasan aspek tata bahasa, kosa kata, dan huruf sangat diperlukan.

Dalam pelaksanaan pembelajaran dokkai shochukyu dosen meminta mahasiswa untuk membaca wacana perkalimat secara bergiliran kemudian menerjemahkan kedalam bahasa Indonesia. Dalam hal ini mahasiswa menggunakan keterampilan yang dimilikinya untuk memahami pola kalimat, termasuk kosakata, huruf kana dan beberapa huruf kanji agar dapat menerjemahkan setiap kalimat dalam wacana tersebut dengan baik dan dapat dimengerti.

Kegiatan ini merupakan bagian dari strategi bottom-up, kegiatan ini dipaparkan dalam hasil observasi pada kegiatan membaca wacana (hon sagyou). 


\section{4) Keterampilan Khusus}

a) Terampil Menerjemahkan dan Memahami Bacaan dalam Huruf dan Bahasa Jepang Tingkat Dasar

Pada proses pembelajaran di kelas, keterampilan mahasiswa dalam menerjemahkan dan memahami bacaan terlihat dari kegiatan mahasiswa membaca wacana, mahasiswa membaca wacana perkalimat secara bergiliran yang kemudian kalimat tersebut langsung diterjemahkan ke dalam bahasa Indonesia. Dengan upaya ini tentunya mahasiswa dituntut harus bisa memahami bacaan, serta huruf agar bisa menerjemahkan kalimat yang dibacanya tersebut dengan baik dan dapat dimengerti.

Kegiatan ini merupakan bagian dari strategi bottom-up, kegiatan ini dipaparkan dalam hasil observasi pada kegiatan membaca wacana (hon sagyou).

\section{Garis Besar Strategi Pengajaran Peer Lesson dan Strategi Bottom-Up dalam Pembelajaran Dokkai Shochukyu}

Secara garis besar pembelajaran yang diterapkan dalam pembelajaran dokkai shochukyu adalah pembelajaran teman sebaya (peer lesson) yang dicirikan dengan setiap topik materi pembelajaran dijelaskan oleh mahasiswa secara berkelompok kepada mahasiswa lainnya pada setiap pertemuan perkuliahan di kelas. Sesuai dengan pengertian strategi peer lesson menurut Silberman (2006 :158). yaitu suatu strategi pembelajaran yang merupakan bagian dari active learning (pembelajaran aktif) strategi yang di desain untuk meningkatkan rasa tanggung jawab siswa secara mandiri dan menuntut saling ketergantungan yang positif terhadap teman sekelompoknya, karena setiap kelompok bertanggung jawab untuk menguasai materi pelajaran yang telah ditentukan dan mengajarkan atau menyampaikan materi tersebut kepada kelompok lain.

Model pembelajaran active learning tipe peer lesson ini digunakan dalam pembelajaran dokkai shochukyu dengan tujuannya agar mahasiswa bisa secara aktif mempelajari, memahami, berdiskusi, menemukan ide pokok dari materi pelajaran, memecahkan persoalan, bertanya, menanggapi dan menjelaskan materi kepada temantemannya. Mahasiswa juga diberi kesempatan untuk memilih cara atau metode yang diinginkan sesuai dengan materi yang di dapatkan untuk bisa menguasai materi pembelajaran yang akan dipresentasikan atau diajarkan kepada temannya.

Strategi bottom-up pada pembelajaran dokkai shochukyu dapat dilihat dari alur penyajian materi pembelajaran, yang penyajiannya dimulai dari hal yang paling kecil yaitu pengenalan/pembelajaran huruf kanji, kemudian secara bergiliran membaca wacana perkalimat dan menerjemahkan wacana tersebut sampai terakhir menuju ketahapan pembelajaran yang lebih besar yaitu menyimpulkan isi wacana. Alur pembelajaran ini sesuai dengan prinsip utama strategi pembelajaran bottom-up, menurut Brown (dalam Subadiyono: 2014:12) yaitu pembelajarannya mulai dari mengidentifikasi huruf dan kata, membaca kalimat dan terus bergerak ketataran yang lebih tinggi, sampai akhirnya menyimpulkan dan memahami isi teks.

Terkait dengan strategi pengajaran bottom-up pada pembelajaran dokkai shochukyu, secara garis besar dapat dipaparkan sebagai berikut.

\section{Pengenalan/Pembelajaran Huruf Kanji dan Kosakata (Atarashii Kotoba)}

Pengenalan/pembelajaran huruf kanji dan kosakata. Huruf kanji dan kosakata yang terdapat dalam wacana diperkenalkan/dijelaskan oleh mahasiswa secara berkelompok kepada mahasiswa lainnya sesuai materi yang didapatkan. Mahasiswa secara berkelompok membuat penjelasan cara baca dan arti kanji tersebut dalam sebuah video kemudian dijadikan sebagai video pembelajaran. Video pembelajaran yaitu video rekaman seluruh anggota kelompok dalam menjelaskan cara baca dan arti kanji tersebut disajikan /dipresentasikan mahasiswa lainnya di kelas. Pembelajaran huruf kanji dan kosakata ini mencirikan strategi pembelajaran teman sebaya (peer lesson).

\section{Membaca dan Menerjemahkan Kalimat}

Membaca dan Menerjemahkan kalimat. Mahasiswa secara bergiliran membaca wacana perkalimat dan menerjemahkan kalimat yang dibacanya kedalam bahasa Indonesia. Dalam 
kegiatan ini mahasiswa dituntut untuk dapat mnerjemahkan kalimat yang dibacanya tersebut dengan baik dan benar, sehingga dapat dimengerti oleh mahasiswa lainnya.

\section{Menyimpulkan Isi wacana}

Menyimpulkan isi wacana, dalam kegiatan ini mahasiswa yang tidak mendapat giliran membaca wacana ditunjuk dosen untuk menyimpulkan seluruh isi wacana secara singkat dengan bahasa Indonesia, hal ini bertujuan untuk memberikan pemahaman kepada semua mahasiswa mengenai inti dari seluruh isi wacana.

\section{Langkah-Langkah Pengajaran dengan Strategi Peer Lesson dan Strategi Bottom-Up dalam Pembelajaran Dokkai Shochukyu.}

Berdasarkan analisis data hasil penelitian yang dilakukan dalam perkuliahan dokkai shochukyu, adapun langkah-langkah pengajaran dalam pembelajaran dokkai shochukyu dengan menggunakan strategi peer lesson dan strategi bottom-up adalah sebagai berikut:

\section{A. Langkah-Langkah Pengajaran dengan Strategi Peer Lesson dalam Pembelajaran Dokkai Shochukyu.}

Strategi peer lesson diterapkan dalam pembelajaran dokkai shochukyu guna untuk mendukung pembelajaran yang aktif dan berpusat pada mahasiswa, dosen mendesain strategi ini untuk memungkinkan pembelajaran sesama teman atau tutor sebaya. Strategi peer lesson diterapkan pada pembelajaran/ pengenalan huruf kanji yang terlihat pelaksanaannya pada tahap mae sagyou atau kegiatan diawal pembelajaran. Adapun langkah-langkah pelaksanaanya adalah sebagai berikut.

a. Pada pertemuan pertama (setelah kontrak kelas) dosen membagi mahasiswa menjadi kelompok, sebanyak segmen materi yang akan dibahas dalam perkuliahan.

b. Masing-masing kelompok mendapat satu wacana sebagai materi tugas. Wacana tersebut diambil dari buku pedoman perkuliahan berjudul みんなの日本語初級1初級で読 めるトピック (minna no nihongo shokyu 1 shokyu yomeru topikku).

c. Setiap kelompok bertugas untuk mencari dan menerjemahkan huruf-huruf kanji dalam wacana dan mencari artinya serta mencari kosakata baru yang ada dalam wacana dan mencari artinya dalam bahasa Indonesia.

d. Atarashii kanji (huruf kanji baru) dan atarashii kotoba (kosakata baru) tersebut kemudian dijelaskan oleh anggota kelompok yang penjelasannya direkam dan dijadikan sebagai video pembelajaran.

e. Video pembelajaran tersebut disajikan atau dipresentasikan kepada mahasiswa lainnya di kelas pada setiap pertemuan perkulihan.

Pada penyampaian penjelasan materi dosen membebaskan mahasiswa untuk menggunakan cara atau metode agar dapat menguasai materi yang disampaikan dan juga dapat dengan mudah dipahami oleh mahasiswa lain. Dalam hal ini dosen hanya sebagai pembimbing belajar mahasiswa serta mengklarifikasi jika ada penyampaian materi yang disampaikan mahasiswa kurang tepat.

Langkah-langkah pembelajaran dengan strategi peer lesson yang digunakan dalam pembelajaran dokkai shochukyu sesuai dengan langkah-langkah pelaksanaan strategi pembelajaran peer lesson yang dipaparkan oleh Zaini (2008:62-63) adalah sebagai berikut.

1. Membagi peserta didik menjadi kelompok sebanyak segmen materi

2. Masing-masing kelompok diberi tugas untuk mempelajari satu topik materi kemudian mengajarkan kepada kelompok lain.

3. Meminta setiap kelompok menyiapkan strategi untuk menyampaikan materi kepada teman-teman sekelas.

4. Memberi waktu cukup untuk mennyiapkan, baik di dalam maupun diluar kelas.

5. Setalah semua kelompok melaksankan tugas, beri kesimpulan dan klarifikasi untuk pemahaman peserta didik.

Strategi peer lesson yang digunakan dalam pembelajaran dokkai shochukyu ini adalah strategi yang mengembangkan peer teaching dalam kelas yang menempatkan 
seluruh tanggung jawab pengajaran kepada seluruh anggota kelas. Dalam penelitian ini yang dimaksud strategi pembelajaran peer lesson adalah pembelajaran yang menuntut mahasiswa belajar mandiri serta mampu menjelaskan materi kepada temannya dalam bentuk kelompok, sehingga dosen disini hanya sebagai fasilitator belajar.

B. Langkah-Langkah Pengajaran dengan Strategi Bottom-Up dalam Pembelajaran Dokkai Shochukyu.

Strategi bottom-up di desain dosen agar mahasiswa dapat belajar dan berinteraksi secara aktif serta komunikatif dalam pembelajaran dokkai shochukyu, proses belajar dengan strategi ini yaitu mahasiswa memahami pembelajaran dimulai dari satuan yang terkecil, yaitu memahami huruf kanji serta kosakata yang dilaksanakan pada tahap mae sagyou atau kegiatan awal pembelajaran, kemudian terus bergerak kesatuan yang lebih besar yaitu memahami kalimat dan paragraf hingga menyimpulkan seluruh isi wacana, pelaksanaan pembelajaran ini dilaksanakan pada tahapan hon sagyou atau kegiatan membaca (inti pembelajaran). Maka dapat digambarkan alur pengajaran dengan strategi bottom-up, sebagai berikut:

\section{A. Kegiatan Awal Pembelajaran (mae sagyou)}

Dosen mengawali perkuliahan dengan menyampaikan salam dan melakukan kegiatan absensi.

\section{Pembelajaran/pengenalan huruf kanji yang dilakukan oleh mahasiswa /Presentasi Mahasiswa}

Mahasiswa secara berkelompok memperkenalkan huruf kanji yang ada dalam wacana sesuai materi yang didapatkan dengan cara mempresentasikan/menyajikan video pembelajaran yaitu video rekaman seluruh anggota kelompoknya dalam menjelaskan atarashii kanji (huruf kanji baru) dan atarashii kotoba (kosakata baru) kepada mahasiswa lainnya di kelas.

\section{B. Kegiatan Membaca/Inti Pembelajaran(hon sagyou)}

Dosen memberikan informasi lisan terkait dengan materi, dengan tujuan untuk memberikan gambaran awal mengenai wacana yang akan dibaca.

\section{Kegiatan Memahami Kalimat/Membaca Kalimat}

Pada tahap membaca dosen meminta mahasiswa membaca wacana secara bergiliran yang dibagi perkalimat kemudian memahami isi wacana dan menerjemahkanya kedalam bahasa Indonesia.

\section{Menyimpulkan isi wacana.}

Guna untuk menyempurnakan pemahaman mahasiswa terhadap kontek dan isi wacana, dosen meminta mahasiswa yang tidak dapat bagian dalam membaca wacana untuk menyimpulkan isi wacana yang telah dibaca tersebut secara singkat dengan bahasa Indonesia.

\section{Kegiatan Akhir Pembelaharan (ato sagyou) \\ Dosen memastikan kembali pemahaman mahasiswa tehadap wacana}

\section{Pengecekan Pemahaman}

Dalam sebuah wacana terdapat beberapa soal atau pertanyaan-pertanyaan dalam tahapan pengecekan pemahaman mahasiswa, dosen membahas soal-soal tersebut secara bersama-sama guna menguatkan pemahaman mahasiswa terhadap wacana yang dibahas

\section{Simpulan dan Saran}

Setelah kegiatan pembahasan soal selesai, terakhir dosen bertanya dengan “じゃ、皆 さん 質問がありますか”。Mahasiswa menanggapi dengan menjawab “いいえ、ありま せん”。Setelah itu, perkuliahan diakhiri perkuliahan dengan mengucapkan “じゃ、質問が なかったら、これ終わりました”。Mahasiswa membalas dengan ucaapan “どうも、あり がとうございます。

Strategi bottom-up dalam pembelajaran dokkai shochukyu merupakan alur pembelajaran yang dipilih untuk menyajikan proses pemahaman dari konteks satuan terkecil, dalam hal ini 
mahasiswa dituntut untuk dapat memahami wacana berbahasa jepang, maka dari itu proses pembelajaranya dokkai shochukyu dimulai dari pengenalan huruf hingga wacana dan menyimpulkan wacana.

Strategi pengajaran yang digunakan dalam pembelajaran dokkai shochukyu pada mahasiswa semester III yaitu strategi peer lesson dan strategi bottom-up. Strategi peer lesson yang digunakan merupakan model strategi active learning yang didesain dosen untuk mendukung pembelajaran aktif berpusat pada mahasiswa serta mendukung pembelajaran sesama siswa/mahasiswa.

Secara garis besar strategi pengajaran peer lesson dalam pembelajaran dokkai shochukyu dapat dilihat penggunaanya pada pembelajaran huruf Kanji, yang mana mahasiswa secara berkelompok dengan aktif menggunakan berbagai cara atau metode dalam membuat dan menyampaikan penjelaskan huruf kanji (atarashii Kanji) dan kosakata (atarashii kotoba) yang ada dalam wacana kepada mahasiswa lainnya dikelas sesuai dengan pembagian materi, hal tersebut dilakasanakan pada setiap pertemuan pembelajaran secara bergantian.

Strategi peer lesson dalam pembelajaran dokkai shochukyu jika dilihat dari urutan penyajian materi pembelajaran dikombinasikan strategi bottom-up. Model pembelajaran bottom up urutan pembelajarannya dimulai dari pengenalan huruf kanji kemudian membaca wacana, menerjahkan dan menyimpulkan wacana dan terakhir penguatan pemahaman yang diisi dengan pembahasan soal pertanyaan yang terdapat dalam wacana.

Langkah-langkah pembelajaran dengan menggunakan strategi pengajaran peer lesson, penerapannya dapat terlihat pada pertemuan pertama kontrak kelas yaitu dosen membagi mahasiswa menjadi kelompok, dan membagikan materi tugas yang harus dikerjakan oleh setiap kelompok mahasiswa yang nantinya tugas tersebut pada tahap mae sagyou yaitu kegiatan awal pembelajaran dipresentasikan atau dijelaskan oleh mahasiswa secara berkelompok kepada mahasiswa lainnya di kelas. Startegi peer lesson yang dikombinasikan dengan strategi bottom-up langkah-langkah pembelajarannya dapat terlihat pada alur penyajian materi pembelajaran yang mana dalam tahap mae sagyou yaitu kegiatan awal pembelajaran dimulai dengan pembelajaran huruf Kanji yang merupakan satuan terkecil kemudian pada tahap hon sagyou yaitu kegiatan membaca/inti pembelajaran dilaksanakan kegiatan membaca wacana dan menerjemahkan serta menyimpulkan wacana yang merupakan satuan yang lebih besar, selanjutnya kegiatan akhir pembelajaran yaitu ato sagyou di isi dengan mereview pemahaman dengan cara membahas soal pertanyaan yang terdapat dalam wacana.

\section{Daftar Pustaka}

Abdul, Majid. 2011. "Perencanaan Pembelajaran Mengembangkan Standar Kompetensi Guru". Bandung: Remaja Rosda Karya.

Apriani, Rini. 2009. Penerapan Metode AQ3R (Survey Question Read Recite Review) Dalam Membaca Pemahaman Teks Bahasa Jepang (Dokkai). Skripsi (tidak diterbitkan). Universitas Pendidikan Indonesia.

Arikunto.Suharsimi.2006. Prosedur Penelitian Suatu Pendekatan Praktik.Jakarta :

Rineka Cipta

Dalman. 2013. Keterampilan Membaca. Jakarta: PT Raja Grafindo Persada.

Himeno, Masako, dkk. (1998). Koko Kara Hajimaru Nihongo Kyooiku. Tokyo: Hitsuji Shoboo.

Hisyam, Zaini. 2008. "Strategi Pembelajaran Aktif'. Yogyakarta: Insan Mandiri

Ishiguro, Kei. 2012. Dokkai to sono oshiekata. Tersedia pada www.jfbkk.or.th/pdf/JL/2012/kiyou2012/01ISHIGURO.pdf. (dikses tanggal 24 November 2017) 
Johnson. 2001 "An Introduction to Foreign Language Learning and Teaching". London: Longman.

Kamus Bahasa Jepang- Indonesia: Matsunaga: Gendai Indonesia Go Jiten, Daigaku Shorin, 1994 (ISBN: 4475000289)

Lexy J. Moleong. 2006. "Metodologi Penelitian Kualitatif". Bandung: Remaja Rosdakarya.

Melvin L. Silbermen. 2006 "Active Leearning: 101 Cara Belajar Siswa Aktif'. Bandung: Nusamedia.

Nurhadi 1995. Tata Bahasa Pendididkan. Semarang: IKIP Semarang Press.

Sudjianto. 2010. "Metode Pengajaran Membaca". Tersedia pada http://repository.ui.ac.id/bitstream/6458/14724/1/07-Sudjianto.pdf (diakses tanggal14 Agustus 2017)

Subadiyono. 2014. "Pembelajaran Membaca". Palembang: NoerFikri Offset.

Sugiyono. 2009. "Metode Penelitian Pendekatan Kualitatif, Kuantitatif dan $R$ \&D”. Bandung: Alfa Beta

Sugiyono. 2012 Metode Penelitian Kuantitatif Kualitatif dan R\&D. Bandung: Alfabeta.

Sugiyono. 2015. Metode Penelitian Pendidikan (Pendekatan Kuantitatif, Kualitatif dan R\&D). Penerbit CV. Alfabeta: Bandung.

Sukardi. 2005. "Metode Penelitian Pendidikan : Kompetensi dan Prakteknya". Jakarta : Bumi Aksara.

Suratno Arsyad Lincoln. 1995. "Metodologi Penelitian Untuk Ekonomi dan Bisnis". Yogyakarta: UPP AMPYKPN.

Sutedi, Dedi. 2011. Penelitian Pendidikan Bahasa Jepang. Bandung: Humaniora.

Supardi, M.D. 2006. "Metodologi Penelitiann". Mataram: Yayasan Cerdas Press.

Henry Guntur, Tarigan. 2008. Membaca Sebagai Suatu Keterampilan Berbahasa. Bandung: Angkasa.

Henry Guntur, Tarigan. 1979. Membaca sebagai Suatu Keterampilan Berbahasa. 